\title{
Growth Factor Receptor-Bound Protein 2
}

National Cancer Institute

\section{Source}

National Cancer Institute. Growth Factor Receptor-Bound Protein 2. NCI Thesaurus. Code C26222.

Growth factor receptor-bound protein 2 (217 aa, $\sim 25 \mathrm{kDa}$ ) is encoded by the human GRB2 gene. This protein is involved in the progression of epidermal growth factormediated signaling pathways. 